\title{
The Role of Financial Institutions in Financing Deficit Budget of Governments
}

\author{
Prof. Mike Anyanwaokoro ${ }^{1,}$ \\ Sir Paschal I. P. Okolie ${ }^{2}$ \\ ${ }^{I}$ Department of Banking and Finance, Faculty of Management Sciences, Enugu State University of Science and \\ Technology, Enugu, Nigeria \\ ${ }^{2}$ Department of Banking and Finance, Faculty of Management Sciences, Enugu State University of Science and \\ Technology, Enugu, Nigeria
}

\begin{abstract}
This brief paper examined the important roles played by Financial Institutions in sourcing funds for financing deficit budgets of Governments. It noted that the financing options could be internal or external depending on the cost of such funds and the regulation in place as at the time of seeking the finance. The paper went further to state that Governments usually make provisions in her budget for sourcing either internal or external loans or both to finance her deficit budgets. In addition, she accounts for the utilization of these loan sources through her Published Annual Statement of Accounts on yearly basis. This paper, which deployed a simple percentage analysis in establishing the relationship between sourced loans and its contribution to funding of Capital projects of Governments concludes that operation of deficit financing of budgets of Governments is good provided that the loans are utilized in funding income generating capital projects that can stimulate the economy and create employments.
\end{abstract}

\section{Introduction}

Governments all over the world exist principally to cater for the welfare and wellbeing of its citizens. According to the 1999 Constitution of the Federal Republic of Nigeria as amended, "the security and welfare of the people shall be the primary purpose of Government" [chapter 2, section 14 sub-section 2(b)]. To achieve this primary objective, Government must plan for its people through future proposals. These future proposals are captured in an official Government document called Budget. However, these budgets, most often, do not contain enough revenues to support the projected expenditure of governments, hence the possibility of deficit budgets. This paper, therefore, will attempt to examine the roles of Financial Institutions in funding the deficit budget of Governments.

\section{The Budget}

A budget is a quantitative expression of a plan for a defined period of time. It may include planned sales volume and revenues, resource quantities, costs and expenses, assets, liabilities and cash flows ... (CIMA Official Terminology).From the above definition, one can define Government budget as an estimate of expected Government revenues and expenditure for the coming financial year. According to a retrieval from Florida International University, "a Government Budget is government document presenting the government's proposed revenues and spending for a financial year that is often passed by the Legislature, approved by the Chief executive or President and prosecuted by the Finance Minister to the nation".

Being a key instrument of fiscal policy, Government budget serves as veritable tool for managing the economy. As a plan of action, it takes into account the scale and allocation of projected Government outlays, revenue profile, all aimed at ensuing the stability of the economy. The stability of the economy guarantees long term economic growth and development which are the ingredient of sustenance of the welfare and well being of the citizens.There are three outcomes of a Government Budget, namely,
(a) Surplus Budget
(b) Balanced Budget
(c) Deficit Budget.

\section{(a) Surplus Budget}

This scenario takes place if projected revenue exceeds projected expenditure. Here, the Government has surplus funds for her planned activities. The challenge therefore, becomes how efficient is the government able to maximize the utilization of the surplus. 
(b) Balanced Budget

This happens when projected revenue equates projected expenditure within the budget year.

\section{(c) Deficit Budget}

Deficit Budget occurs when projected revenue for the budget year is less than the projected expenditure within the same period. The challenge here is how government is going to source for this deficit to finance the budget. At this point, the role of Bank and other financial Institutions come into play.

\section{Deficit Budgeting By Governments}

Deficit budgeting, as stated earlier, is a situation where the projected revenue is less than projected expenditure within a financial year. The term is mostly used to refer to government spending that could not be supported by the revenues generated within the period under consideration. When this happens, Government resort to alternative sources of funding to augment the deficit. The budget deficit is therefore the annual amount which the government borrows to shore up the shortfall in revenue accruing to it. The size of budget deficit is usually measured as a percentage of Gross Domestic Product (GDP). For instance, the Fiscal Responsibility Act, 2007 provides that budget deficit should not exceed 3 percent of Nigeria GDP. Meanwhile, Budget deficit occurs as a result of:

(a) Poor Management of the economy by Government.

(b) Inability of big companies and other tax payers to pay their fair share of their taxes.

(c) General low tax revenues because of financial crisis.

(d) Spending on big or white elephant projects.

(e) Expanding expenditure on recurrent spending by Government

Whether budget deficit is beneficial or not depends on:

(a) Timing of the deficit; if it is carried out during economic recession, it is beneficial.

(b) Why the Government is borrowing; if Government borrowed to fund infrastructure, it is beneficial.

(c) The cost of the borrowing; if the cost of borrowing is less, it is beneficial.

(d) The future prospect of economic growth.

According to Tejvan Pettinger, Governments should be concerned about a budget deficit for the following reasons:

a. Countries with large deficit may struggle to attract investors to buy bonds.

b. There is a fear that budget deficits could be inflationary.

c. Cutting the deficit can cause problems. This happens if a country has a deficit that increases too quickly, it may adopt a policy aimed at sharp deficit reduction which can occasion economic problems.

d. Increasing national debt. If the budget deficit increases above a certain level, a higher percentage of national income is spent on debt interest payments.

After considering the far reaching implications of deficit budgets, Government goes ahead to adopt it with adequate provisions on the sources of funding such deficits. This could be through Internal or External loan sources duly provided for in the relevant budget year. For instance, the table 1 below shows the provision of Internal and External sources of funding the deficit budget of Enugu State Government from 2010 to 2014. It also reveals the percentage contribution of projected loans to projected capital receipts over the period under review.

Table 1

\begin{tabular}{|l|l|l|l|l|l|}
\hline Table Showing Budgeted Sources of Fund for financing Defic Budget of Enugu State From 2010 To 2014 \\
\hline \multirow{2}{*}{ SOURCE OF FUNDING } & $\mathbf{2 0 1 0}$ & $\mathbf{2 0 1 1}$ & $\mathbf{2 0 1 2}$ & $\mathbf{2 0 1 3}$ & $\mathbf{2 0 1 4}$ \\
\cline { 2 - 6 } & Billion & Billion & B Billion & Billion & Billion \\
\hline Internal Loan & 16.086 & 12.000 & 5.550 & 3.841 & 5.461 \\
\hline External Loan & 6.060 & 4.557 & 3.057 & 3.500 & 11.444 \\
\hline Total & $\mathbf{2 2 . 1 4 6}$ & $\mathbf{1 6 . 5 5 7}$ & $\mathbf{8 . 6 0 7}$ & $\mathbf{7 . 3 4 1}$ & $\mathbf{1 6 . 9 0 5}$ \\
\hline Overall Capital Receipts & $\mathbf{2 9 . 0 2 9}$ & $\mathbf{2 6 . 3 2 8}$ & $\mathbf{4 4 . 9 7 1}$ & $\mathbf{4 7 . 4 5 5}$ & $\mathbf{5 4 . 4 0 5}$ \\
\hline \% of Total Loan to Capital Receipts & & & & $\mathbf{3}$ & $\mathbf{3 1 . 0 7}$ \\
& $\mathbf{7 6 . 2 9}$ & $\mathbf{6 2 . 8 9}$ & $\mathbf{1 9 . 1 4}$ & $\mathbf{1 5 . 4 7}$ &
\end{tabular}

Sources:

1 Enugu State of Nigeria Budget Estimates 2010 Official Document 2010, P.3

2 Enugu State of Nigeria Supplementary Budget Estimates 2011 Official Document No. 2, 2011, P.2 
3 Enugu State of Nigeria Supplementary Budget Estimates 2012 Official Document No. 2, 2012, P.2

4 Enugu State of Nigeria Supplementary Budget Estimates 2013 Official Document No. 2, 2013, P.6

5 Enugu State of Nigeria Approved Budget 2014 Official Document 2014, P.3

From the above table which shows the percentage of projected loan to projected capital receipts as provided in the budget confirms the relevance of Banks and other financial Institution in funding deficit budgets.

\section{The Role Of Banks/Financial Institutions In Funding Budget Deficits.}

As seen in the above table, loan sources (internal and external) are provided for funding Government deficit budgets. The internal sources of funding comes from Banks while external sources comes from World Bank, International Development Association (IDA), ADB/UNIDO, etc. For instance, the deficit of $\$ 2.22$ trillion (equivalent of $2.16 \%$ of Nigerian GDP) in the Federal Budget will be financed by a combination of domestic borrowing of $\$ 984$ billion and foreign borrowing of $\$ 903$ billion totaling $\$ 1.84$ trillion.

According to Prof. Mike Akwanashie, financing budget deficit can be met by government running down its cash resources, selling some of its assets like properties, printing more currency and using it (ways and means) or through short term borrowing from the banking system. From this, it can be seen that Banks play vital roles in funding deficit budgets. Table 2 below which shows the Actual loan obtained by Enugu State Government to finance Capital Expenditures from 2010 to 2014 goes to support role of Banks in deficit budget funding.

Table 2

\begin{tabular}{|l|l|l|l|l|l|}
\hline Table Showing Actual Loans obtained to Finance Enugu State Capital Expenditure \\
\hline \multirow{2}{*}{ ACTUAL LOANS OBTAINED } & $\mathbf{2 0 1 0}$ & $\mathbf{2 0 1 1}$ & $\mathbf{2 0 1 2}$ & $\mathbf{2 0 1 3}$ & $\mathbf{2 0 1 4}$ \\
\cline { 2 - 6 } & Billion & Billion & B Billion & B Billion & Billion \\
\hline Internal Loan & 8.409 & 8.307 & 4.007 & 1.000 & 3.595 \\
\hline External Loan & 1.452 & 1.550 & 1.493 & 2.406 & 0.757 \\
\hline Total & $\mathbf{9 . 8 6 1}$ & $\mathbf{9 . 8 5 7}$ & $\mathbf{5 . 5 0 0}$ & $\mathbf{3 . 4 0 6}$ & $\mathbf{4 . 3 5 2}$ \\
\hline Overall Capital Receipts & $\mathbf{2 6 . 2 8 6}$ & $\mathbf{4 1 . 8 8 2}$ & $\mathbf{2 6 . 9 2 0}$ & $\mathbf{3 7 . 3 4 1}$ & $\mathbf{3 8 . 2 8 4}$ \\
\hline \% of Total Loan to Capital Receipts & $\mathbf{3 7 . 5 1}$ & $\mathbf{2 3 . 5 4}$ & $\mathbf{2 0 4 3}$ & $\mathbf{9 . 1 2}$ & $\mathbf{1 1 . 3 7}$ \\
\hline
\end{tabular}

Sources:

1 Report of the Accountant General with financial Statements for 2010, P.36

2 Report of the Accountant General with financial Statements for 2011, P.26

3 Report of the Accountant General with financial Statements for 2012, P.26

4 Report of the Accountant General with financial Statements for 2013, P.25

5 Report of the Accountant General with financial Statements for 2014, P.26

The above table indicates that $37.51 \%, 23.54 \%, 20.43 \%, 9.12 \%$ and $11.37 \%$ of total loan (internal and external) helped in funding Enugu State Government deficit budget for 2010, 2011, 2012, 2013 and 2014 respectively. The level of infrastructural facilities like quality roads, electricity, investments in agriculture, etc in place in Enugu State within the five years under consideration goes to justify the benefit of financing deficit budgets by Financial Institutions.

\section{Conclusion}

In the present economic reality, most governments operate deficit budgets. The dwindling revenue from oil and other tax revenues make deficit budgeting imperative. Operating deficit budgets is not bad if the loan sourced from Banks and other financial Institutions are deployed for future income generating capital investments like infrastructure, Industry, Agriculture, etc that can grow the economy through creation of employment, expanding export that will strengthen the local currency. It therefore follows that if Nigeria manages her 2016 deficit budget well, it can pull the country out of the impending recession staring it in the face.

\section{References/Webliograghy}

[1]. Akwanashe M, "Deficit Budgeting, Government Borrowing, Borrowing cost, Economics Ahmadu Bello University, Zaria.

[2]. Breakdown of Nigeria 2016 Budget

[3]. Constitution of the Federal Republic of Nigeria, 1999 as amended.

[4]. Enugu State of Nigeria Approved Budget 2014 Official Document 2014, P.3

[5]. Enugu State of Nigeria Approved Supplementary Budget Estimates 2012 Official Document No. 2, 2012, P.2

[6]. Enugu State of Nigeria Approved Supplementary Budget Estimates 2013 Official Document No. 3, 2013 , P.6

[7]. Enugu State of Nigeria Budget Estimates 2010 Official Document 2010, P.3

[8]. Enugu State of Nigeria Supplementary Budget Estimates 2011 Official Document 2011, P.2

[9]. Fiscal Responsibility Act, 2007

[10]. https://en.m.wikipedia.org > wiki>Budget, CIMA Official Terminology 
[11]. https://en.m.wikipedia.org>wiki>gov. Public Budgeting and Financial Management; Florida International University, Retrieval November 21, 2013.

[12]. Report of the Accountant General financial Statements for 2010, P.36

[13]. Report of the Accountant General with financial Statements for 2011, P.26

[14]. Report of the Accountant General with financial Statements for 2012, P.26

[15]. Report of the Accountant General with financial Statements for 2013, P.25

[16]. Report of the Accountant General with financial Statements for 2014, P.26

[17]. Tejvan Petinger, March 9, 2013 economics, "How important is the budget deficit" 